\title{
Effect of Waste Paper on Biogas Production from Co-digestion of Cow Dung and Water Hyacinth in Batch Reactors
}

\section{MOMOH, O.L. YUSUF; NWAOGAZIE, L. Ify*}

\author{
Department of Civil and Environmental Engineering, \\ University of Port-Harcourt, Choba, P.M.B. 5323, Port Harcourt. \\ E-mail:yusuf_mom@yahoo.com; ifynwaogazie@yahoo.com. +2348035386779 OR +2348033399923
}

\begin{abstract}
The effect of waste paper on biogas production from the co-digestion of fixed amount of cow dung and water hyacinth was studied at room temperature in five batch reactor for over 60 days. Waste paper addition was varied for a fixed amount of cow dung and water hyacinth until maximum biogas production was achieved. Biogas production was measured indirectly by water displacement method. The production of biogas showed a parabolic relationship as the amount of waste paper (g) increased with a goodness of fit of 0.982 . Maximum biogas volume of 1.11 liters was observed at a waste paper amount of $17.5 \mathrm{~g}$ which corresponded to $10.0 \%$ total solids of the biomass in $250 \mathrm{ml}$ solution. Thus, an optimum waste paper amount of $17.5 \mathrm{~g}$ needs to combine with $5 \mathrm{~g}$ of cow dung and $5 \mathrm{~g}$ of water hyacinth in $250 \mathrm{ml}$ of water for maximum biogas production. Similar equivalents in kilograms and tonnes can be utilized in large-scale production of biogas which can provide decentralized source of fuel for university laboratories and also local supply of energy for electricity production. Also, the air pollution problems associated with open burning of waste papers can be eliminated. The biogas process has established to be cheap and practically feasible. @ JASEM
\end{abstract}

The anaerobic digestion of organic materials has long been used to generate useful resources, which have been harnessed for the use of mankind. Biogas, which is one of the byproducts of anaerobic digestion, comprises about $60 \%$ methane and $40 \%$ carbon dioxide. It has been used as a source of fuel in countries like India, China, Sweden, Bangladesh etc. for lighting and cooking purposes. In addition co-digestion of organic waste with sludge or cow dung has been mentioned in the works of Anhuradha et al (2007) and Godliving (2007) with improvements in biogas production. Apart from biogas, useful soil conditioner and manure have been obtained from the slurry residual after anaerobic digestion. Organic sources of biogas generation abound in the environment and these are well documented in literature. Works of authors like Jain et al (1981), Dunlop (1978) and Jash and Basu (1999) have studied biogas generation from animal and agricultural wastes.

Biogas, being a renewable source of energy has the potential of supplementing other available energy sources in a bid to encouraging the principles of sustainable development, and reduces the practice of total dependence on fossil oil that are finite. This research work explores a suitable way to use organic waste in the environment - cow dung, which constitutes a serious problem in abattoirs, served as useful raw material for this research, because it contains the necessary micro-organism (acid formers and the methane formers) for biogas production. Waste paper at dumpsites from administrative offices, educational institutions etc, was another raw material. Finally, water hyacinth, which is rich in nitrogen and other essential nutrients (Mark and Ken, 2006) usually responsible for clogging water ways, affecting navigation, fishing and recreational activities (Mark and Ken, 2006) was also another raw material for the research work.

\section{MATERIALS AND METHOD}

Cow dung from abattoirs situated in Choba community, waste paper was collected from dumpsites situated at the University of Port Harcourt premises and water hyacinth harvested from water ways situated in Ahoada community all in Rivers State.

\section{Materials}

The materials used for this experiment were cow dung, waste paper, and water hyacinth. Pretreatment operations involved weighing about $500 \mathrm{~g}$ of freshly harvested water hyacinth and allowing it to sun dry for a period of 30 days, after which they were dried in an oven at $60^{\circ} \mathrm{C}$ for 5hours. This oven-dried water hyacinth was then ground to fine particles using a grinding mill. Similar operations were applied to the waste paper. However, the cow dung was sun dried for a period of 20 days to preserve its microbial population and then crushed mechanically using a mortar and pestle. The dry weights of these biomasses were weighed with a weighing balance (Mettler PN 163) into digesters.

\section{Experimental}

A set of five batch reactors were used as digesters. Each digester contained fixed amount of cow dung and water hyacinth, but an increasing amount of waste paper. These digesters were labeled A, B, C, $\mathrm{D}$, and $\mathrm{E}$, respectively. The digester labeled A, had no waste paper, $5 \mathrm{~g}$ of cow dung and $5 \mathrm{~g}$ of water hyacinth. This digester acted as the control. Compositions of other batch reactor digesters B to E are as follows:

(i) Digester -B consisted of $4 \mathrm{~g}$ of waste paper, $5 \mathrm{~g}$ of cow dung and $5 \mathrm{~g}$ of water hyacinth.

(ii) Digester-C consisted of $8 \mathrm{~g}$ of waste paper, $5 \mathrm{~g}$ of cow dung and $5 \mathrm{~g}$ of water hyacinth.

(iii) Digester-D consisted of $12 \mathrm{~g}$ of waste paper, $5 \mathrm{~g}$ of cow dung and i5g of water hyacinth. 
(iv) Digester-E consisted of $20 \mathrm{~g}$ of waste paper, $5 \mathrm{~g}$ of cow dung and $5 \mathrm{~g}$ of water hyacinth.

These biomasses were mixed with $250 \mathrm{ml}$ of water and then corked to exclude air. The experimental set-up is depicted in the Figure 1. The contents of digesters were allowed to ferment for a period of 62 days and agitated twice daily, the morning and evening hours, respectively. Biogas measurement was carried out using water displacement method (Itodo et al, 1992)

Ambient temperature measurements were determined using a thermometer. The average $\mathrm{pH}$ of the digester mixtures were determined before and after experiment with a $\mathrm{pH}$ meter (PN 209).

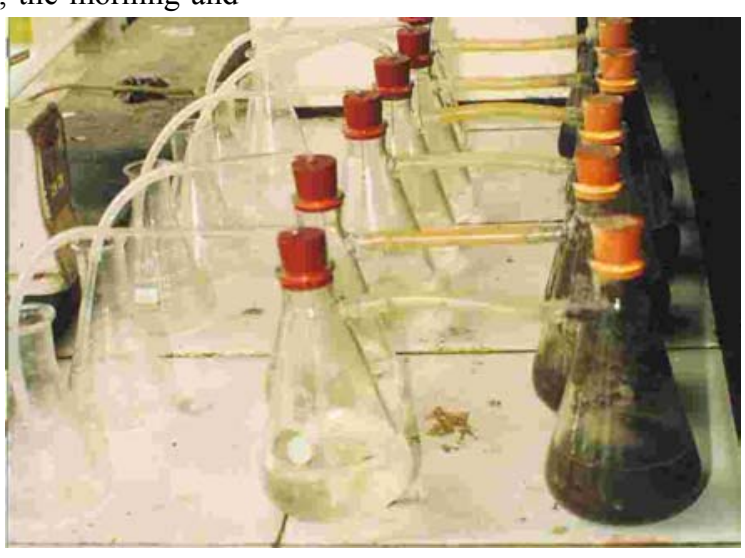

Figure1. Biogas production set-up

\section{RESULTS AND DISCUSSION}

The average $\mathrm{pH}$ values of batch reactors as determined before and after experiment are shown in Table 1 Also the total solids composition in each digester are presented in Table 2. It was observed that the $\mathrm{pH}$ before experiment was within the optimum range for biogas production that is 6.67.6. After the experiment, $\mathrm{pH}$ values were observed to increase slightly which is consistent with work of Shoeb and Singh (2000). The slight increase in $\mathrm{pH}$ after anaerobic digestion can be explained based on the fact that organic nitrogen were readily reduced to ammonium ion $\left(\mathrm{NH}_{4}\right), \mathrm{pH}$ values observed were between 7.35 - 7.96 after digestion. The temperature variation for the period under study had a 2- day minimum of $23^{\circ} \mathrm{C}$ and a 2-day maximum of $29^{\circ} \mathrm{C}$. The average temperature for the period of study was $26^{\circ} \mathrm{C}$.

Table 1: $\mathrm{pH}$ values of Digesters A-E before and after digestion

\begin{tabular}{lcl}
\hline Digester & \multicolumn{2}{c}{$\mathrm{pH}$ - values of biomass mixture } \\
& Before digestion & After digestion \\
$\mathrm{A}$ & 7.18 & 7.96 \\
$\mathrm{~B}$ & 6.81 & 7.57 \\
$\mathrm{C}$ & 6.71 & 7.35 \\
$\mathrm{D}$ & 6.69 & 7.40 \\
$\mathrm{E}$ & 6.41 & 7.35 \\
\hline
\end{tabular}

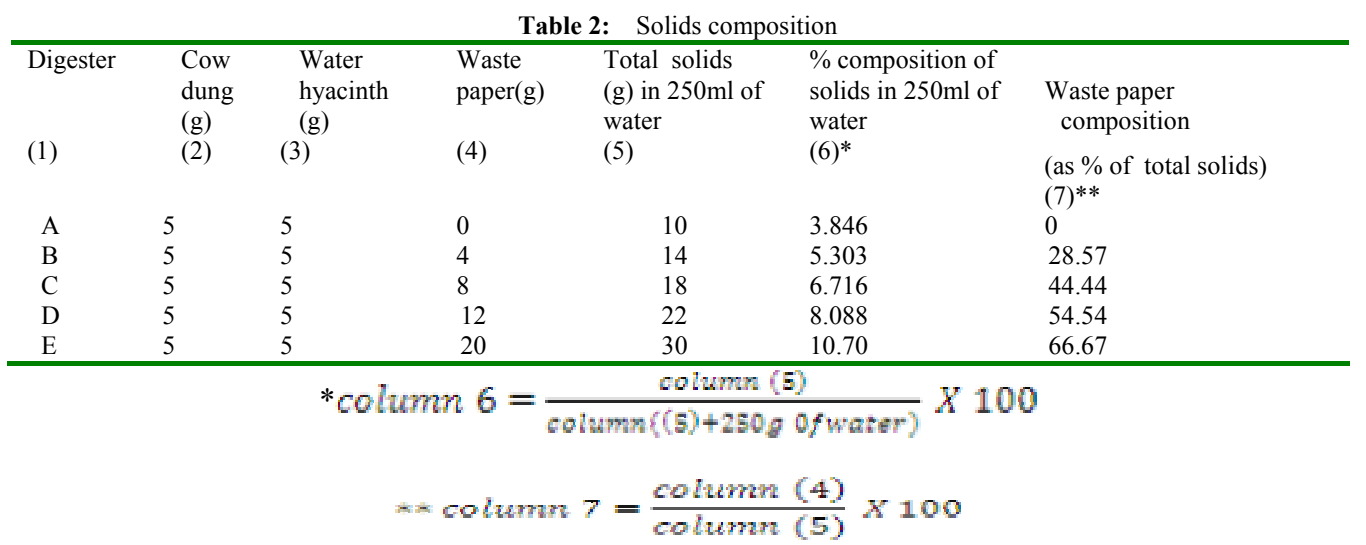

Note: density of water is $1 \mathrm{~g} / \mathrm{ml}$

The relationship between the total biogas produced and the amount of waste paper $(\mathrm{g})$ fed into the digesters is shown to follow a parabolic relationship as depicted by Fig. 2 defined by equation 1 with a goodness of fit of 0.982 . $y=-0.002 x^{2}+0.088 x+0.343$.

Where $\mathrm{y}$ represents total biogas production and $\mathrm{x}$ represents amount of waste paper $(\mathrm{g})$. A maximum biogas production of 1.11 liters was observed at a waste paper amount of $17.5 \mathrm{~g}$ which lies 
somewhere between digester D and E. Above this value biogas production begins to decline. In essence increasing amount of waste paper does not lead to an indefinite increase in biogas production. Many reasons have been proposed for this phenomenon like reduced mass transfer rate of substrates to bacteria or accumulation of inhibitory substances (Vandervivere et al, 2002).

However, the relationship between and the percent (\%) total solid concentration in $250 \mathrm{ml}$ of water (column (6)) and amount of waste paper (g) (column(4)) in Table 2 for the five digesters A-E, showed a linear curve fit represented by Equation (2) depicted in Fig. 2 with a goodness of fit equal to 0.999

$y=0.342 \mathrm{x}+3.918$

Where $\mathrm{x}$ represents waste paper concentration $(\mathrm{g})$ and $\mathrm{y}$ represents percent $(\%)$ of total solids in $250 \mathrm{ml}$ of water.

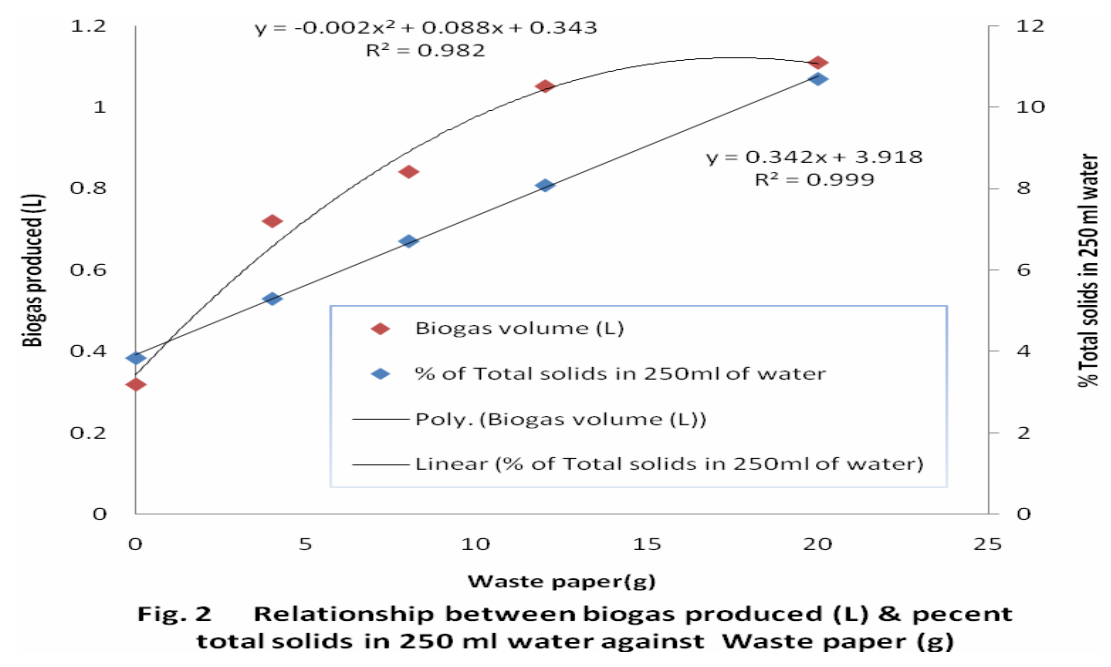

This equation can be use as a regression model to deduce percent (\%) total solids concentration equivalent to producing maximum biogas volume. Hence, upon substituting $17.5 \mathrm{~g}$ of waste paper for (x) yield a (y) value of 10\%. This percent of total solids is what is needed for maximum biogas production. Vandervivere et al (2002), suggested $10-15 \%$ total solids for a one stage anaerobic wet system digestion of municipal solid wastes. In essence $17.5 \mathrm{~g}$ of waste paper needs to combine with $5 \mathrm{~g}$ of cow dung and $5 \mathrm{~g}$ of water hyacinth in $250 \mathrm{ml}$ of water for maximum biogas production.

Conclusion and Recommendation: The anaerobic digestion of cow dung, water hyacinth and waste paper is feasible at room temperature. However the effect of waste paper on fixed amount of cow dung and water hyacinth was found to increase biogas production in a parabolic manner. In this research, it was observed that a waste paper concentration of $17.5 \mathrm{~g}$ is the maximum amount of waste paper needed to combine with $5 \mathrm{~g}$ of cow dung and $5 \mathrm{~g}$ of water hyacinth for maximum production of biogas. This can be translated to kilograms or tonnes for large scale production of biogas.

Acknowledgment: It is with profound gratitude we expressed our sincere appreciation to the Department of Chemistry, University of Port Harcourt, for providing the necessary assistance for this research work. Special thanks also go to the Faculty of Engineering University of Port Harcourt for their support during the course of the research work.

\section{REFERENCES}

Anhuradha, S; Vijayagopal, V; Radha, P; Ramanujam, R (2007).Kinetic Studies and Anaerobic Co-digestion of Vegetation Market and Sewage Slugde, CLEAN-Soil, Air, Water Vol. 35 pp 197-199.

Dunlop, CE (1978). In Single Cell Protein II, Tannenbaum S.R. and Wans D.LC. (Eds) MIT Press CambrIdge, Massachusetts, pp 244-262.

Itodo, L N; Lucas EB; Kucha E1(1992). The Effect of Media Material and its Quality on Biogas Yield. Nigerian Journal of Renewable Energy 3, Nos. 1 and 2 pp. 45-49.

Godliving, Y; Mtui, S (2007).Trends in Industrial and Environmental Biotechnology Research in Tanzania, African Journal of Biotechnology Vol. 6 No. 25 pp 2860-2867.

Jain, MK; Sigh, R; Taure, P(1981).Anaerobic Digestion of Cattle Waste, Agricultural Waste 3, pp. 65-73.

Jash, T; Basu. S(1999). Development of a MiniBiogas Digester for Lighting in India, ENERGY 24; 409-411.

Mark, AM and Ken, AL (2006).Florida Crop/Pest Management Profile; Aquatic Weed, http://www.edis.ifas.ufl.edu) 
Shoeb, F; Singh, J.H (2000). Kinetics of Biogas Evolved from Water Hyacinth, $2^{\text {nd }}$ International Symposium on New Technologies for Environmental Monitoring and Agroapplication, Turkey.

Steffen, R; Szolar, O; Braun, R. (2000),Feed stock for anaerobic digestion, AD Nett report 2000.
"Anaerobic Digestion: Making Energy and Solving Modem Waste problem".

Vandervivere, P; Baere, L; Verstrete,W (2002). Types of Anaerobic digester for solid waste, www.ees.adelaide.edu.au/pharis/biogas/pvdv.p 